\title{
On the Vulnerability of the Egyptian Mediterranean Coast to the Sea Level Rise
}

\begin{abstract}
By Tarek M. El-Geziry*
Sea level rise (SLR) along the Egyptian Mediterranean coast was valued using tide gauge data. There is considerable difference in both mean sea level and rate of increase in different parts of this stretched coastal zone. The tide gauge station at Sidi Abdel-Rahman showed a SLR of $1.0 \mathrm{~mm} / y e a r$. SLR at Alexandria Western Harbour and Mersa Matrouh was 2.2 and $2.4 \mathrm{~mm} /$ year, respectively. The SLR along the central Delta region was observed as $3.8 \mathrm{~mm} / y e a r$ at Burullus. The stations in Port Said and Abu-Qir showed a SLR of $4.8 \mathrm{~mm} / y e a r$ and $6.4 \mathrm{~mm} / y$ r, respectively. Moreover, physical vulnerability of the coast to changes in sea level was evaluated revealing that the Delta coastal zone is very high vulnerable to any SLR. In contrast, vulnerability along the western section of the Egyptian Mediterranean coast varies from moderate to high.
\end{abstract}

Keywords: Egypt, Mediterranean, sea level, sea level rise, rates, vulnerability

\section{Introduction}

Global sea level has risen at a rate of $1.8 \mathrm{~mm} /$ year over the $20^{\text {th }}$ century as a consequence of the global temperature rise (IPCC 2007). This sea level rise (SLR) distresses coastal ecosystems (IPCC 2007, Nicholls et al. 2007) in numerous ways, e.g. coastal erosion, saltwater intrusion, flooding, etc. It will also affect the coastal communities and economies. As a low-elevated coast, the Egyptian Mediterranean coast is greatly vulnerable to SLR (El-Raey et al. 1999, Dasgupta et al. 2009, Syvitski et al. 2009, El-Deberky and Hunicke 2015). The projected SLR of $0.5 \mathrm{~m}$ in the $21^{\text {st }}$ century may affect over $1800 \mathrm{~km}^{2}$ of agricultural land and almost 3.8 million people in the Nile Delta from Alexandria to Port Said (Fitzgerald et al. 2008). All these factors reflecting the importance of monitoring the sea level variations along the Egyptian Mediterranean coast motivated this analysis of sea level, which includes a set of sea level data covering the Egyptian Mediterranean coast excluding its most eastern side off El-Arish and Rafah. Assessing vulnerability to SLR at different parts of the Egyptian Mediterranean coast is also examined in this study.

\section{The Egyptian Mediterranean Coast}

The Egyptian Mediterranean coast covers a length of about $1200 \mathrm{~km}$ from Rafah $\left(31^{\circ} 17^{\prime} 19^{\prime \prime} \mathrm{N} ; 34^{\circ} 14^{\prime} 28^{\prime \prime} \mathrm{E}\right)$ in the east to Sallum $\left(31^{\circ} 30^{\prime} 13^{\prime \prime} \mathrm{N} ; 25^{\circ} 06^{\prime} 54^{\prime \prime} \mathrm{E}\right)$ in the west (Figure 1). It comprises four different sections based on the physiographical characteristics. Therefore, coastal dynamical features are expected

*Associate Research Professor, Laboratory of Physical Oceanography, Division of Marine Environment, National Institute of Oceanography and Fisheries (NIOF), Egypt. 
to differ from one section to another. The northwest Egyptian Mediterranean region (Section 1), extending from Sallum to Alamein, is featured by the highest elevation above the mean sea level (MSL) along the entire Egyptian Mediterranean coastline (Santamaria and Farouk 2011). Section 2, extending from Alamein to Alexandria, is the middle northern Egyptian Mediterranean region. This comprises Alexandria Western Harbour, which is the main Egyptian port on the Mediterranean. Then comes the Nile Delta section (Section 3), which stretches between Rosetta and Port Said. This is characterised by the largest population density in Egypt, and it is the main area where the agriculture activities exist. Lastly, the most eastern section (Section 4) is the north-eastern Egyptian Mediterranean region extending from Port Said to Rafah. It comprises the main zone of Egypt industrial and commercial activities, including the Suez Canal. Along this prolonged coast, five coastal lakes, namely: Mariut, Edku, Burullus, Manzalah and Bardawil, from west to east, respectively, are in connection with the Mediterranean Sea. In addition to this coastal lake system, the Egyptian Mediterranean coast is featured by the presence of ports and harbours of different activities, e.g., Alexandria and Port Said (Commercial and industrial harbours), ElBurullus (fishing harbour).

Figure 1. The Mediterranean Basin with the Geographical Sections of the Egyptian Mediterranean Coast and Locations of Tide Gauges used in the Present Study

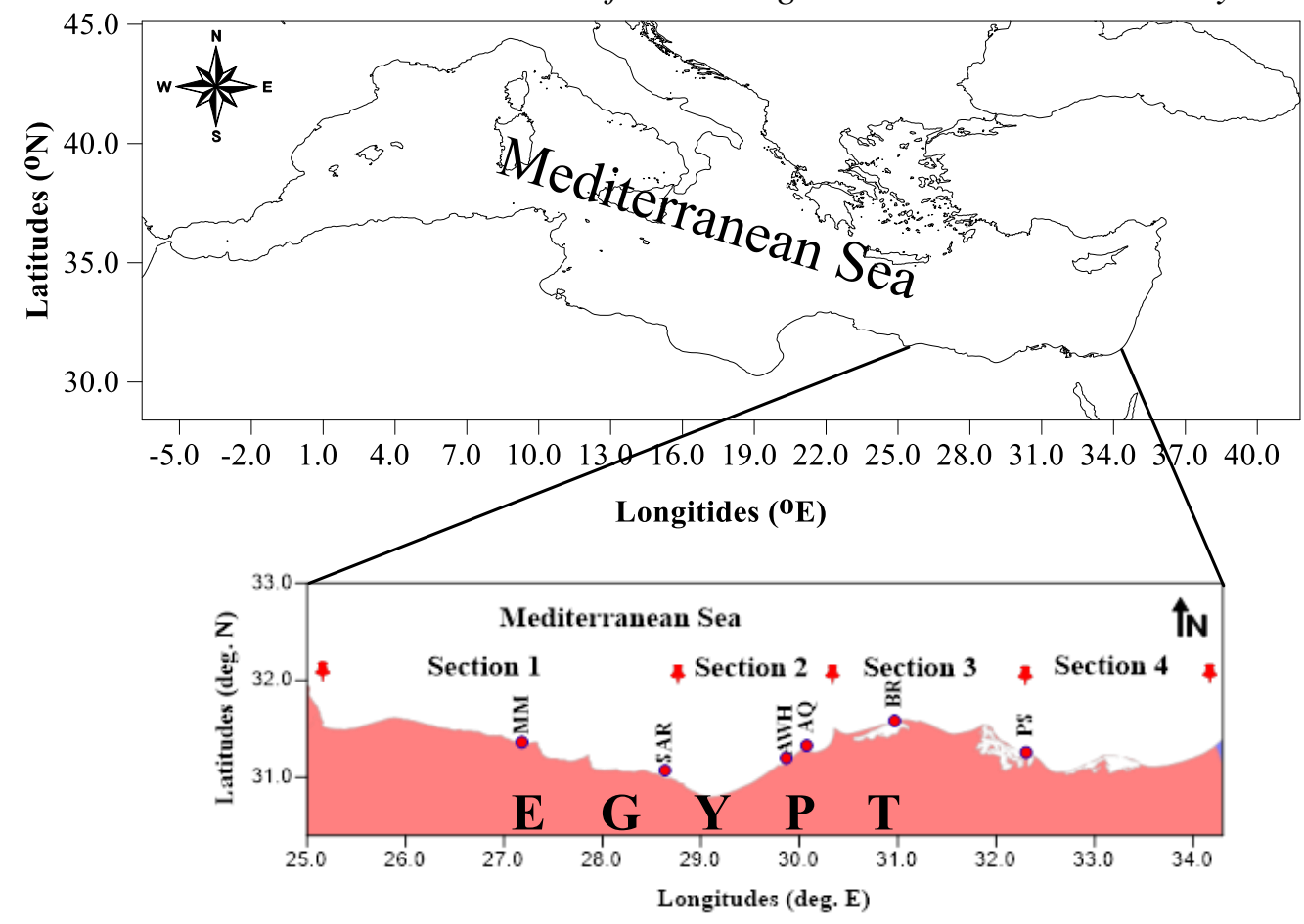

Sea Level Rise along the Egyptian Mediterranean Coast

The sea level variation along the Egyptian Mediterranean coast is the result of the combined effects of astronomical tides and surge elevations. Tides are mainly semidiurnal, with a dominant tidal range in the order of a few centimetres (Hussein 
et al. 2010, Saad et al. 2011, El-Geziry and Radwan 2012, Said et al. 2012, Radwan and El-Geziry 2013). Surges, being affected by the meteorological conditions, may reach a height of $1.0 \mathrm{~m}$ (El-Geziry and Radwan 2012), and therefore, have more impact on the coast.

The coastal zone of the Egyptian Mediterranean Sea is exposed to numerous environmental stresses, which are mostly attributed to the anthropogenic activities associated with urban, industrial and agricultural development; producing pollutants of land-based sources (UNDP 2011). The SLR along the Mediterranean coast of Egypt is a major problem, and it has been recognised as highly vulnerable to climate change induced-SLR (UNDP 2014). Dasgupta et al. (2009) classified Egypt in the top ten most affected countries by SLR. The Nile and Niger Deltas were identified as the most threatened African deltas due to subsidence and human interference (Syvitski et al. 2009). Alexandria was ranked $11^{\text {th }}$ in terms of population exposed to coastal flooding in 2070s (El-Deberky and Hunicke 2015).

Several studies on the vulnerability of Alexandria indicated that a $0.3 \mathrm{~m}$ SLR would affect large parts of the city resulting in loss of billions of dollars infrastructure, displacement of over half a million inhabitants and in a loss of about 70,000 jobs (El-Raey et al. 1999). With a $1 \mathrm{~m} \mathrm{SLR}$, it is estimated that $68 \%(1,200$ $\mathrm{km}^{2}$ ) of Alexandria land could be inundated (Leatherman and Nicholls 1995). Alexandria is experiencing a SLR with a rate of $2.2 \mathrm{~mm} / \mathrm{yr}$ (El-Geziry and Said 2020). Additionally, Alexandria is subsiding at a rate of $2 \mathrm{~mm} / \mathrm{yr}$ and even without climate change, the city is highly vulnerable to flooding and erosion, as $35 \%$ (700 $\mathrm{km}^{2}$ ) of the land area is below the mean sea level (El-Raey et al. 1995). Maiyza and El-Geziry (2012) showed that the land subsidence in the vicinity of Alexandria has the major impact on the observed sea level variations over the oceanographic and environmental factors. Chen et al. (1992) and Warne and Stanley (1993) calculated the land subsidence rate along Alexandria to vary between 0.5 and $7 \mathrm{~mm} / \mathrm{yr}$. Frihy (2003) examined the impacts of the SLR along the coast of the Nile Delta. He identified four main sections along the Nile Delta Coast as most vulnerable to SLR including; Burullus and Manzala lakes, western backshore zone of Abu Qir Bay, Manzala-Port Said area, and Ras El-Barr Beach. The study estimated that about $30 \%$ of the Nile Delta coast would be vulnerable to SLR. He also concluded that the land subsidence rate at Port Said and the Nile Delta is $5 \mathrm{~mm} / \mathrm{yr}$. According to Stanley (1997) the rate of the Nile Delta subsidence is relatively lower than that of the other river deltas in the Mediterranean Basin: Rhone, Po and Ebro, which can examine a subsidence up to $10 \mathrm{~mm} / \mathrm{yr}$. The Nile Delta is not only affected by SLR but also by the problem of land subsidence. The risk assessment of exposure in Kafr El-Sheikh Governorate in the Nile Delta region, based on the B1 and A1FI scenarios of the IPCC (2007) revealed that no noteworthy altration was detected between the 2 scenarios with respect to the SLR impacts (Hassaan 2013). Among the ten districts of the Governorate, more than $40 \%$ of the total area of five districts is expected to be lost due to inundation by SLR. Port Said is Egypt's second largest harbour examines a SLR rate of $4.8 \mathrm{~mm} / \mathrm{yr}$ (El-Geziry and Said 2020). It is also suffering from a land subsiding at $5 \mathrm{~mm} / \mathrm{yr}$, and therefore, the SLR there would become more severe 
than other parts of the Egyptian Mediterranean coast (El-Raey 1997). In case of a $0.5 \mathrm{~m}$ SLR, a loss of $1.6 \%\left(21 \mathrm{~km}^{2}\right)$ beach area, $8 \%\left(0.46 \mathrm{~km}^{2}\right)$ urban area, and $13 \%\left(0.05 \mathrm{~km}^{2}\right)$ industrial area, in addition to other physical and socio-economic damages would be expected in Port Said Governorate, costing a lot beyond US\$2.2 billion (El-Raey et al. 1999, Agrawala et al. 2004).

Different approaches were proposed and investigated by Koraim et al. (2011); to protect the northern coast of Egypt from the SLR. This includes the soft construction techniques, the barriers, the coastal armoring, the elevated development, the floating development, the floodable development, managed retreat and the integrated coastal zone management approach.

\section{Sea Level Rise in Coastal Vulnerability Index}

Vulnerability is strongly correlated with the rate of the SLR. Rates of relative sea level variations are significant inputs in the calculations of a coastal vulnerability index. This index is one of the prognostic methods to coastal classification by combining several variables from natural and human environments from a variety of sources (McLaughlin and Cooper 2010). Moreover, a coastal vulnerability index helps to evaluate and classify responses to progressive changes and modifications in the dynamic of any coastal zone (Hamid et al. 2019). All studies consider that a lower SLR rate or a fall in the sea level (negative values) represents the least vulnerable coast (Gornitz 1991, Gornitz and White 1991), as shown in Table 1. Moreover, small intervals are used on coasts where the range of the sea level change is small (Abuodha and Woodroffe 2010), and higher intervals are used where a high range of sea level exists (Ozyurt and Ergin 2010).

Table 1. Vulnerability of Coastal Zone on the Basis of Relative SLR Rates

\begin{tabular}{|l|c|c|c|c|c|}
\hline Reference & Very low & Low & Moderate & High & Very high \\
\hline Gornitz (1991) & $\leq-1.1$ & $-1.0-0.99$ & $1.0-2.0$ & $2.1-4.0$ & $\geq 4.1$ \\
\hline Gornitz and White (1991) & $\leq-1.1$ & $-1.0-0.99$ & $1.0-2.0$ & $2.1-5.0$ & $\geq 5.1$ \\
\hline Abuodha and Woodroffe (2010) & $<0.0$ & $0.0-0.9$ & $1.0-2.0$ & $2.1-3.0$ & $>3.1$ \\
\hline Ozyurt and Ergin (2010) & $<1.0$ & $1.0-2.0$ & $2.0-5.0$ & $5.0-7.0$ & $>7.0$ \\
\hline
\end{tabular}

\section{Data and Methods of Analysis}

The present work is using hourly sea level records from six tide gauges installed along the Egyptian Mediterranean coast (Figure 1), at Mersa Matrouh (MM), Sidi Abdel-Rahman (SAR), Alexandria Western Harbour (AWH), Abu-Qir Bay (AQ), Burullus new harbour (BR) and Port Said (PS) from west to east, respectively. The period of data differs from one location to another (Table 2). The recorded sea level at each location is referred to the zero level of the instrument.

The MSL is frequently defined as the average value of hourly sea levels recorded over a period of at least one year period, and preferably over about 19 years; to average over the 18.61 years cycle in the tidal amplitudes and phases, and to average out weather (Pugh and Woodworth 2014). Therefore, the MSL in the 
present work is calculated as the arithmetic average of the hourly sea levels from each tide gauge at every location. The MSL is referred inhere to the tide gauge zero level.

Table 2. Locations, Positions and Periods of Sea Level Records in the Present Study

\begin{tabular}{|l|c|c|c|c|}
\hline \multirow{2}{*}{ Tide Gauge Location } & \multicolumn{2}{|c|}{$\begin{array}{c}\text { Tide Gauge } \\
\text { Position }\end{array}$} & \multirow{2}{*}{$\begin{array}{c}\text { Period of } \\
\text { REcords }\end{array}$} & $\begin{array}{c}\text { \% of missed } \\
\text { data }\end{array}$ \\
\cline { 2 - 3 } & $\begin{array}{c}\text { Lat. } \\
\text { (deg. N) }\end{array}$ & $\begin{array}{c}\text { Long. } \\
\text { (deg. } \text { E) }\end{array}$ & & 0 \\
\hline Mersa Matrouh (MM) & 31.256 & 32.305 & $\begin{array}{c}4 \text { years } \\
(2003-2006)\end{array}$ & 0 \\
\hline Sidi Abdel-Rahman (SAR) & 31.582 & 30.968 & $\begin{array}{c}5 \text { years } \\
(2012-2016)\end{array}$ & 0 \\
\hline Alex. Western Harbour (AWH) & 31.325 & 30.075 & $\begin{array}{c}33 \text { years } \\
(1974-2006)\end{array}$ & 9.1 \\
\hline Abu-Qir Bay (AQ) & 31.199 & 29.866 & $\begin{array}{c}21 \text { years } \\
(1990-2010)\end{array}$ & 0 \\
\hline Burullus (BR) & 31.07 & 28.636 & $\begin{array}{c}6 \text { years } \\
(2003-2008)\end{array}$ & 0 \\
\hline Port Said (PS) & 31.36 & 27.183 & $\begin{array}{c}8 \text { years } \\
(2003-2010)\end{array}$ & 0 \\
\hline
\end{tabular}

\section{Results}

\section{Sea Level Changes}

Based on the available hourly data the MSL at the six locations is calculated to be 32, 35, 48, 48, 62 and $67 \mathrm{~cm}$ at MM, SAR, AWH, AQ, BR and PS, respectively. This reveals a general behaviour of declination in the sea surface from east to west, with a difference of $35 \mathrm{~cm}$ between the two sides. Moreover, the sea level range (difference between high and low water levels) is 17, 4, 20, 10, 20 and $40 \mathrm{~cm}$ at MM, SAR, AWH, AQ, BR and PS, respectively.

Changes in the rates of SLR along the Egyptian Mediterranean coast indicate significant variation between the calculated rates in the different parts of this coastline. These rates were recently calculated by El-Geziry and Said (2020) to be $1.0 \mathrm{~mm} /$ year at SAR, 2.2 and $2.4 \mathrm{~mm} /$ year at AWH and MM, respectively, 3.8 $\mathrm{mm} /$ year at BR, and 4.8 and $6.4 \mathrm{~mm} /$ year at PS and AQ, respectively. Generally speaking, the sea level change along the western part of the Egyptian Mediterranean coast shows low rise rates in contrast to its eastern part. The overall rate of the SLR along the Egyptian Mediterranean coast is $3.4 \mathrm{~mm} / \mathrm{yr}$ (El-Geziry and Said 2020). 


\section{Vulnerability of the Egyptian Mediterranean Coast to Sea Level Rise}

The relative vulnerability of different coastal environments to the SLR may be measured on a regional to national scale using elementary information on coastal geomorphology, SLR rate, past shoreline evolution, mean tidal range, and mean wave height (Thieler and Hammar-Klose 1999, Ozyurt and Ergin 2010). A considerable variation has been observed in the calculated rates of mean annual sea level rise along the Egyptian Mediterranean coast. As the sea level ranges are generally low along the Egyptian Mediterranean coast, the vulnerability index by Abuodha and Woodroffe (2010) will be applied in this study.

With respect to the calculated SLR rates, vulnerability of the Egyptian Mediterranean coast to sea level rise variates from high to very high, except the region of SAR, which can be classified as moderately vulnerable. Taking the land subsidence rate into consideration, the calculated rates become higher: The northwest section of the Nile Delta comprising AWH and AQ is believed to be subsiding by $3.7 \mathrm{~mm} /$ year, while the central section comprising $\mathrm{BR}$ has a subsidence rate of $7.7 \mathrm{~mm} / \mathrm{yr}$ (Stanley and Clemente 2017). Thus, the relative SLR of these three coastal zones becomes 5.9, 10.1 and $11.5 \mathrm{~mm} /$ year, respectively.

The northeast sector of the Nile Delta coast comprising PS demonstrated a high rate of SLR. The calculation revealed a rate of $4.8 \mathrm{~mm} / \mathrm{year}$ (El-Geziry and Said, 2020). After incorporating local land level subsidence, which is estimated to be $8.4 \mathrm{~mm} / \mathrm{yr}$ (Stanely and Clemente 2017), the relative rise exceeds $13 \mathrm{~mm} /$ year.

Because of these high rates of relative SLR, the coastal zone from Alexandria to Port Said has been considered as a very high vulnerable coast (Figure 2).

On the other hand, the western sector of the Egyptian Mediterranean Coast comprising SAR and MM has examined a low rate of SLR of $1.0 \mathrm{~mm} / \mathrm{yr}$ and 2.4 $\mathrm{mm} / \mathrm{yr}$, respectively (El-Geziry and Said 2020). Unfortunately, no information is available at present on land subsidence and its rate in this sector. Therefore, the extent of the SLR in this western coastal zone can be treated as moderate to high vulnerable (Figure 2).

Figure 2. Vulnerability of the Egyptian Mediterranean Coast to Sea Level Change

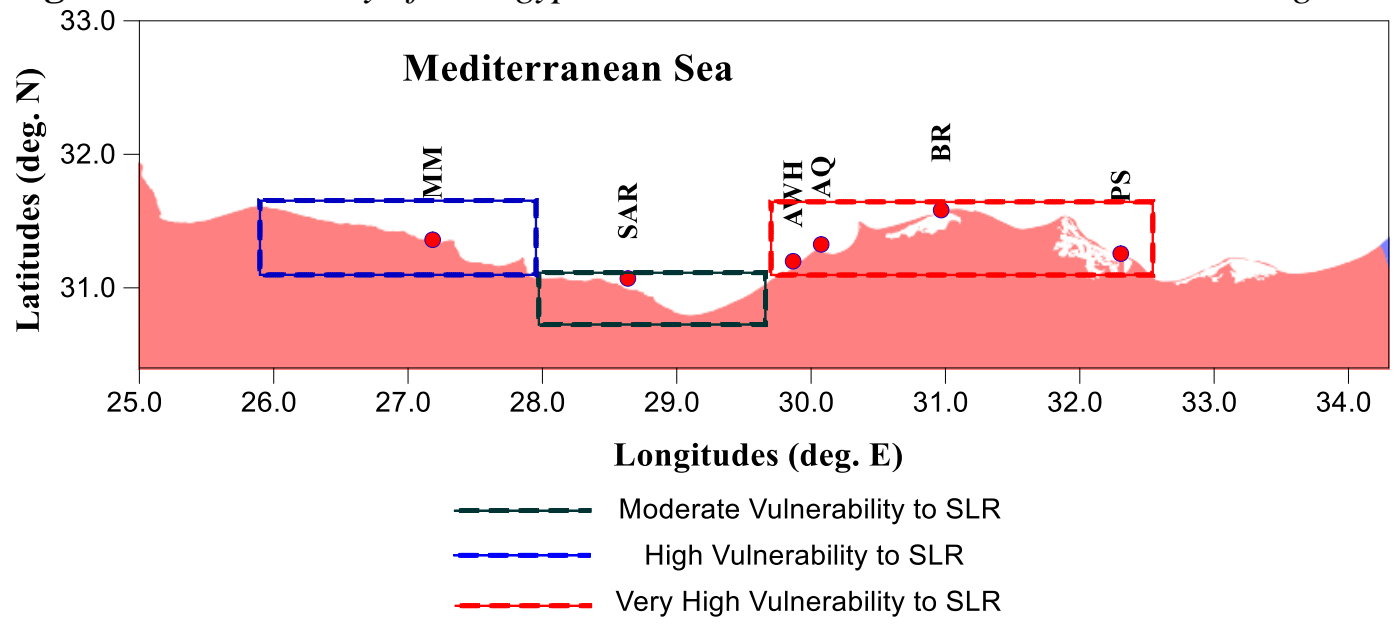


From a tidal range point of view, the Egyptian Mediterranean coast can be categorised as having microtidal range. The region that has a microtidal range characteristic is determined as a very high vulnerable to SLR (Abuodha and Woodroffe 2010, Ozyurt and Ergin 2010). This is mainly attributed to the potential influence and greatest risk of storm impact on the coastline versus to the tidal range effect.

\section{Discussion}

Being classified as low-elevated coastal zone, the Egyptian Mediterranean coast has got special attention because of potential hazards from the sea level rise (SLR).

Data availability and quality are great concerns in assessing rates and behavior of the SLR. Tide-gauge data from six tide-gauges distributed along the Egyptian Mediterranean coast were used to calculate the MSL and ranges in the present work. The rates of the SLR were recently calculated by El-Geziry and Said (2020) using the same data sets. The deployment locations represent the four different sections of the Egyptian Mediterranean coast.

Results revealed significant variations in the calculated MSL along the Egyptian Mediterranean coast, with a general slope of declination from east (PS) to west (MM). This is in consistent with the atmospheric pressure system of Lows and Highs impacting on the Levantine Basin (Tsimplis et al. 2005, Gomis et al. 2008, Oddo et al. 2014). The present results on the tidal ranges assure the microtidal pattern of the Egyptian Mediterranean coast. This is in agreement with the classification of Manohar (1981) and Hereher (2015). Rates of SLR along the different parts of the coast are varying and changeable at the local scale but meanwhile point out a general pattern of increase over the whole coast. The overall average rate of SLR along the Egyptian Mediterranean coast is calculated to be about $3.4 \mathrm{~mm} / \mathrm{yr}$ (El-Geziry and Said 2020), which is larger than the global SLR rate for the $20^{\text {th }}$ century of $1.8 \pm 0.5 \mathrm{~mm} / \mathrm{yr}$ (Church and White 2011) and for the whole Mediterranean basin rates of 1.1-1.3 mm/yr (Tsimplis and Baker 2000). However, this rate is less than that calculated for the Eastern Mediterranean of 04$20 \mathrm{~mm} / \mathrm{yr}$ (Tsimplis et al. 2008, Vigo et al. 2011, Passaro and Seitz 2012). It worth declaring the mid-to-east sector of the Egyptian Mediterranean coast comprising AQ, BR and PS is affected by higher SLR rates than its mid-to-west sector (AWH, SAR and MM). This may be a direct result of the pronounced land subsidence taking place in this eastern region of the Egyptian Mediterranean coast. The SLR at SAR, AWH and MM stations have shown rates of 1.0, 2.2 and $2.4 \mathrm{~mm} /$ year, respectively. The SLR obtained at AQ was the highest, being $6.4 \mathrm{~mm} / \mathrm{yr}$. At BR and PS, the SLR rate was 3.8 and $4.8 \mathrm{~mm} / \mathrm{yr}$, respectively. These rates are in agreement with those previously calculated over different periods and at different locations along the Egyptian Mediterranean coast (e.g., El-Fishawi and Fanos 1989, Frihy 1992, 2003, Shaker et al. 2011, Said et al. 2012, Maiyza and El-Geziry 2012). 
Vulnerability is tightly related to the number of people affected by a hazard and their adaptive capacity. Hence the use of the term "vulnerability" in the present work, which mainly assessed physical vulnerability of the coastal zone toward the SLR, might undermined its true meaning in the disaster reviews or development terminology. Abuodha and Woodroffe (2010) have chosen to use the term "sensitivity" instead, to explain the susceptibility of a coast. The assessment of vulnerability could be practiced by integrated sensitivity with affected environment, population and their adaptive response variables. The sea level rise imposes the greatest threat to the Egyptian Mediterranean coast along its central part comprising the Nile Delta with its two extremities including cities of Alexandria and Port Said. The Delta coast is composed of flat deltaic sediments for a distance of about $250 \mathrm{~km}$ as a consequence of the long-lasting Nile River flooding (Hereher 2015). According to the present analysis, this part of the Egyptian coastal zone densely populated and where lands are very fertile is classified as very high vulnerable zone to sea level rise. This comes in agreement with the conclusions of El-Hattab (2015) and Hereher (2015). Generally speaking, the geomorphology of the coast between Sidi Abdel Rahman and Mersa Matrou to Sallum $(\sim 250 \mathrm{~km})$ is a rocky calcareous rocks beach with a natural vertical cliffs sloping (Frihy 2009). The area between Alexandria and Alamein $(\sim 100 \mathrm{~km})$ is generally low cliffy coast (Hereher 2015). The present results revealed that the coastal zone of the most far western coastal region of Mersa Matruh is high vulnerable and that around Sidi Abdel Rahman zone is moderately vulnerable to the SLR. This contradicts with Hereher's conclusion that this area has a low to a very low vulnerability. This contradiction may be attributed to the consideration of only one parameter in the present work, i.e. sea level, to highlight areas susceptible and vulnerable to the sea level rise problem along the Egyptian Mediterranean Coast.

\section{Conclusions}

In conclusion, the calculated SLR rates along the Egyptian Mediterranean Coast are within the known categories of both global and Mediterranean rates. The sea level ranges are also in agreement with the known ranges of this coastal zone. The varying vulnerability classification to SLR along the Egyptian coast is mainly attributed to the different composition of strata over this coast and to the different behaviour and rates of land subsidence. Planning to overcome the impacts of sea level changes and land subsidence trends in the coastal zones requires management attention. These areas must be kept in top priority in dealing with this slow but highly destructive natural threat. A coastal vulnerability index can thus afford awareness concerning the virtual potential of coastal damage caused by sealevel rise and land subsidence. Despite the fragmented availability of data, this study provides a limited but prospective assessment of the Egyptian Mediterranean coast's vulnerability to future SLR. The created sea-level rise vulnerability map will assist coastal planners to handle the natural threat in more efficient way. 


\section{Acknowledgment}

The author would like to thank Prof. Mohamed A. Said, Emeritus Professor of Physical Oceanography, National institute of Oceanography and Fisheries (NIOF), for providing the sea level data used to calculate the MSL and the sea level ranges in the present study.

\section{References}

Abuodha P, Woodroffe CD (2010) Assessing vulnerability to sea-level rise using a coastal sensitivity index: a case study from southeast Australia. Journal of Coastal Conservation 14(3): 189-205.

Agrawala S, Moehner A, El Raey M, Conway D, van Aalst M, Hagenstad M et al. (2004) Development and climate change in Egypt: focus on coastal resources and the Nile. Organisation for Economic Co-operation and Development (OECD).

Chen Z, Warne AG, Stanley DJ (1992) Late quaternary evolution of the northwest Nile delta between Rosetta and Alexandria, Egypt. Journal of Coastal Research 8(3): 527-561.

Church JA, White NJ (2011) Sea-level rise from the late $19^{\text {th }}$ to the early $21^{\text {st }}$ century. Surveys in Geophysics 32(4): 585-602.

Dasgupta S, Laplante B, Murray S, Wheeler D (2009) Sea-level rise and storm surges: a comparative analysis of impacts in developing countries. Policy Research Working Paper (WPS 4901). Washington, DC: World Bank Group.

El-Deberky Y, Hunicke B (2015). Vulnerability of the Nile delta to recent and future climate change. In Proceedings of the $36^{\text {th }}$ IAHR World Congress, The Netherlands, 28 June-3 July, 2015.

El-Fishawi NM, Fanos AM (1989) Prediction of sea-level rise by 2100, Nile delta coast. INQUA, Commission on Quaternary Shorelines Newsletter 11: 43-47.

El-Geziry T, Radwan A (2012) Sea level analysis off Alexandria, Egypt. Egyptian Journal of Aquatic Research 38(1): 1-5.

El-Geziry TM, Said MA (2020) Spatial variations of sea level along the Egyptian Mediterranean coast. Athens Journal of Mediterranean Studies 6(2): 141-154.

El-Hattab MM (2015) Improving coastal vulnerability index of the Nile delta coastal zone, Egypt. Journal of Earth Science and Climatic Change 6(8): 293-299.

El-Raey M (1997) Vulnerability assessment of the coastal zone of the Nile delta, Egypt, to the impacts of sea level rise. Ocean and Coastal Management 37(1): 29-40.

El-Raey M, Nasr S, Frihy O, Desouki S, Dewidar K (1995) Potential impacts of accelerated sea-level rise on Alexandria Governorate, Egypt. Journal of Coastal Research 14: 190-204.

El-Raey M, Frihy O, Nasr S, Desouki S, Dewidar K (1999) Vulnerability assessment of sea level rise over Port Said Governorate, Egypt. Environmental Monitoring and Assessment 5(2): 113-128.

Fitzgerald DM, Fenster MS, Argow BA, Buynevich IV (2008) Coastal impacts due to sealevel rise. Annual Review of Earth and Planetary Sciences 36(1): 601-647.

Frihy OE (1992) Sea-level rise and shoreline retreat of the Nile delta promontories, Egypt. Natural Hazards 5(Jan): 65-81.

Frihy OE (2003) The Nile delta-Alexandria coast: vulnerability to sea-level rise, consequences and adaptation. Mitigation and Adaptation Strategies for Global Change 8(2): 115-138. 
Frihy OE (2009) Morphodynamic implications for shoreline management of the westernMediterranean sector of Egypt. Environmental Geology 58(6): 1177-1189.

Gomis D, Ruiz S, Sotillo MG, Álvarez-Fanjul E, Terradas J (2008) Low frequency Mediterranean Sea level variability: the contribution of atmospheric pressure and wind. Global and Planetary Change 63(2-3): 215-229.

Gornitz V (1991) Global coastal hazards from future sea level rise. Palaeogeography, Palaeoclimatology, Palaeoecology (Global and Planetary Change Section) 89(4): 379-398.

Gornitz V, White TW (1991) The global coastal hazards data base. In Future Climate Studies and Radio-Active Waste Disposal, Safety Studies, 214-224. England.

Hamid AIA, Din AHM, Yusof N, Abdullah NM et al. (2019) Coastal vulnerability index development: a review. In $6^{\text {th }}$ International Conference on Geomatics and Geospatial Technology (GGT 2019), Kuala Lumpur, Malaysia.

Hassaan MA (2013) GIS-based risk assessment for the Nile delta coastal zone under different sea level rise scenarios case study: Kafr EL Sheikh Governorate, Egypt. Journal of Coastal Conservation 17(4): 743-754.

Hereher ME (2015) Coastal vulnerability assessment for Egypt's Mediterranean coast. Geomatics, Natural Hazards and Risk 6(4): 342-355.

Hussein M, Moursy Z, Tayel M (2010) General pattern of Alexandria western harbor sea level change. Journal King Abdul-Aziz University (JKAU), Marine Science 21(2): $47-61$.

Intergovernmental Panel on Climate Change - IPCC (2007) Climate change 2007: the physical science basis. Contribution of Working Group I to the Fourth Assessment Report of the Intergovernmental Panel on Climate Change. S Solomon, D Qin, M Manning, Z Chen, M Marquis, KB Averyt et al. (eds). Cambridge, UK and New York, USA: Cambridge University Press.

Koraim AS, Heikal EM, Abo Zaid AA (2011) Different methods used for protecting coasts from sea level rise caused by climate change. Current Development in Oceanography 3(1): 33-66.

Leatherman SP, Nicholls RJ (1995) Accelerated sea-level rise and developing countries: an Overview. Journal of Coastal Research 14: 1-14.

Maiyza IA, El-Geziry TM (2012) Long term sea-level variation in the south-eastern Mediterranean Sea: a new approach of examination. Journal of Operational Oceanography 5(2): 53-59.

Manohar M (1981) Coastal processes at the Nile delta coast. Shore Beach 49: 8-15.

McLaughlin S, Cooper JA (2010). A multiscale coastal vulnerability index: a tool for coastal managers. Environmental Hazards 9(3): 233-248.

Nicholls RJ, Wong PP, Burkett VR, Codignotto JO, Hay J, Mclean R et al. (2007) Coastal systems and low-lying areas. In ML Parry, OF Canziani, JP Palutikof, PJ van der Linden, CE Hanson (eds), 315-356. Climate Change 2007: Impacts, Adaptation and Vulnerability. Contribution of WG II to the Fourth Assessment Report of the Intergovernmental Panel on Climate Change. Cambridge, UK: Cambridge University Press.

Oddo P, Bonaduce A, Pinardi N, Guarnieri A (2014) Sensitivity of the Mediterranean sea level to atmospheric pressure and free surface elevation numerical formulation in NEMO. Geoscientific Model Development 7(6): 3001-3015.

Ozyurt G, Ergin A (2010) Improving coastal vulnerability assessments to sea-level rise: a new indicator-based methodology for decision makers. Journal of Coastal Research 26(Mar): 265-273. 
Passaro M, Seitz F (2012) Steric sea level variations in the central-eastern Mediterranean Sea from Argo observations. Bollettino di Geofisica Teorica ed Applicata 52(1): 131-147.

Pugh D, Woodworth $\mathrm{Ph}$ (2014) Sea-level science understanding tides, surges, tsunamis and mean sea level. Cambridge, UK: Cambridge University Press.

Radwan A, El-Geziry T (2013) Some statistical characteristics of surges at Alexandria, Egypt. Journal King Abdul-Aziz University: Marine Sciences 24(2): 31-38.

Saad NN, Moursy ZA, Sharaf El-Din SH (2011) Water heights and weather regimes at Alexandria Harbor. International Journal of the Physical Sciences 6(30): 7035-7043.

Said MA, Moursy ZA, Radwan AA (2012) Climatic change and sea level oscillations off Alexandria, Egypt. In Proceedings of International Conference on Marine and Coastal Ecosystems. Albania, 353-359.

Santamaria RM, Farouk M (2011) Study area characterisation. In Environmental Hydraulics Institute "IH Cantabria" (eds), 16-39. Integrated Coastal Zone Management Plan for the Coastal Areas between Marsa Matruh and El-Sallum, Egypt.

Shaker AA, Saad AA, Al-Naggar D, Faisal H (2011) Absolute sea-level rise estimation at Alexandria using tide records and GPS observations. In FIG Working Week 2011, Bridging the Gap between Cultures, Marrakech, Morocco, 18-22 May 2011.

Stanley DJ (1997) Mediterranean deltas: subsidence as a major control of relative sealevel rise. Monaco: Bulletin of Institute of Oceanography.

Stanley JD, Clemente PL (2017) Increased land subsidence and sea-level rise are submerging Egypt's Nile delta coastal margin. GSA Today, Geological Society of America 27(5): 4-11.

Syvitski JPM, Kettner AJ, Overeem I, Hutton EWH, Hannon MT, Brakenridge R et al. (2009) Sinking deltas due to human activities. Nature Geoscience 2(10): 681-686.

Thieler ER, Hammar-Klose ES (1999) National assessment of coastal vulnerability to sealevel rise, US Atlantic coast (Open-File Report no. 99-593, 1 sheet). Woods Hole (MA): United States Geological Survey.

Tsimplis MN, Baker TF (2000) Sea level drop in the Mediterranean Sea: an indicator of deep water salinity and temperature changes. Geophysical Research Letters 27(12): 1731-1734.

Tsimplis MN, Alvarez-Fanjul E, Gomis D, Fenoglio-Marc L, Perez B (2005) Mediterranean Sea level trends: atmospheric pressure and wind contribution. Geophysical Research Letters 32(20): L20602.

Tsimplis M, Marcos M, Somot S (2008) $21^{\text {st }}$ century Mediterranean sea level rise: steric and atmospheric pressure contributions from a regional model. Global and Planetary Change 63(2-3): 105-111.

United Nations Development Program - UNDP (2011) Egypt's national strategy for adaptation to climate change and disaster risk reduction. United Nations Development Program.

United Nations Development Program - UNDP (2014) Adaptation to climate change in the Nile delta through integrated coastal zone management. United Nations Development Program.

Vigo MI, Sánchez-Realesa JM, Trottini M, Chaoc BF (2011) Mediterranean Sea level variations: analysis of the satellite altimetric data, 1992-2008. Journal of Geodynamics 52(3-4): 271-278.

Warne AG, Stanley DG (1993). Late Quaternary evolution of the northwest Nile delta and adjacent coast in the Alexandria region, Egypt. Journal of Coastal Research 9(1): 26-64. 
